\title{
ARTICLE \\ The Clash of Powers in Poland's Rule of Law Crisis: Tools of Attack and Self-Defense
}

\section{Marcin Matczak ${ }^{1}$ iD}

Published online: 19 August 2020

(c) The Author(s) 2020

\begin{abstract}
Many people must be wondering how it is possible that Poland, not so long ago hailed for its exemplary transition from a communist dictatorship to a liberal democracy, could have so swiftly descended into authoritarianism via a crisis in the rule of law. The majority of commentators point to the size and ferocity of the attack on those mechanisms meant to safeguard the rule of law, whereas few focus on the weakness of their defence. This article attempts to redress that imbalance. The crucial facts of the Polish crisis are first presented, and the nature of both the attacks on the rule of law in Poland and the measures taken in its defence are then presented. In describing their defence, this article not only draws on Nicholas Barber's concept of the self-defence of institutions, but attempts to improve upon it in the light of the Polish crisis. Further in the article, I argue that one of the reasons for the success of the assault on the rule of law is the formalistic legal mindset that is prevalent among Polish lawyers. This mindset is characterized by a reductionism of the interpretative premises to be applied when deciding constitutional cases. This reductionism is conspicuous in the application of bright-line rules with no consideration of general constitutional principles. I argue that the development of a robust, non-formalistic methodology of legal decision-making is a prerequisite for a successful defence of the rule of law.
\end{abstract}

\section{Introduction}

Many people must be wondering how it is possible that Poland, which not so long ago was lauded for its exemplary transition from a communist dictatorship to a liberal democracy, could have so swiftly descended into authoritarianism via a crisis in

Marcin Matczak

marcinsmatczak@gmail.com

1 Faculty of Law and Administration, University of Warsaw, Krakowskie Przedmiescie 26/28, 00-927 Warsaw, Poland 
the rule of law. ${ }^{1}$ How is it that the defences erected to prevent a relapse into authoritarianism, viz. independent constitutional and judicial review, have been so easily undermined?

The majority of commentators point to the size and ferocity of the attack on those mechanisms meant to safeguard the rule of law, while a few focus on the weakness of their defence. This article attempts to redress that imbalance. I first present the crucial facts of the Polish crisis, and then present both the nature of the attacks on the rule of law in Poland and the defence mounted against them. In describing this defence, I not only draw on Nicholas Barber's concept of the self-defence of institutions, but attempt to improve upon it in the light of the Polish crisis.

Further in the article, I argue that one of the reasons for the success of the assault on the rule of law is the formalistic legal mindset that is prevalent among the Polish judiciary and legal profession. This mindset is characterized by a reductionism of the interpretative premises to be applied when deciding constitutional cases, most conspicuous in the application of bright-line rules with no consideration of general constitutional principles.

This article discusses three crucial moments in the Polish rule of law crisis, viz. the government's commandeering of the Constitutional Tribunal (CT) in 2016, and the National Council of the Judiciary (NCJ) and the Supreme Court (SC) in 2017/2018, and shows how an unduly formalist approach to constitutional law has enabled the government to achieve its objectives. I argue that the same formalistic mindset has made it impossible for Polish judges to defend themselves against this flagrant abuse of power.

The conclusion I come to is that judicial formalism, commonly perceived as a tool for establishing the rule of law, can nonetheless contribute to its destruction. The Polish experience shows that the development of a robust, non-formalistic methodology of legal decision-making, one which makes use of general constitutional principles, is a prerequisite for the defence of the rule of law.

\section{Facts}

\subsection{Introduction}

A systemic constitutional crisis in the Republic of Poland erupted in November 2015, immediately after the Law and Justice party (the PiS) won the country's parliamentary elections. The first stage of this crisis consisted of cancelling the earlier appointment of five CT judges and 'packing' the CT (the judicial body responsible for the constitutional review of legislation) with new judges, ${ }^{2}$ and in a series of

\footnotetext{
1 I use the term "authoritarianism" as it is used in Glasius (2018). Glausius defines authoritarian practices as "patterns of action that sabotage accountability to people over whom a political actor exerts control, or their representatives, by means of secrecy, disinformation and disabling voice" and distinguishes them from illiberal practices ("patterned and organized infringements of individual autonomy and dignity").

2 Sadurski (2019b, p. 66).
} 
attempts to commandeer the CT by enacting six bills aimed at paralyzing its operations. ${ }^{3}$ This first stage ended in December 2016, when a new CT President was appointed by the President of the Republic of Poland.

The second stage of the crisis started in 2017 and consisted of the political takeover of the NCJ, the constitutional body responsible for protecting the independence of the judiciary and for appointing and promoting judges, ${ }^{4}$ as well as in commandeering the SC. ${ }^{5}$

All in all, Poland's rule-of-law crisis has resulted in:

(a) paralyzing the $\mathrm{CT}^{6}$;

(b) subjecting the previously autonomous NCJ to the legislature and the Minister of Justice (MoJ), thereby politicizing judicial appointments ${ }^{7}$;

(c) several attempts to remove SC judges from their positions and politically motivated dismissals and appointments of court presidents and vice-presidents. ${ }^{8}$

\subsection{Commandeering the $\mathbf{C T}$}

In November 2015, the newly elected Parliament, in which the PiS gained a majority in both houses, nullified the appointment of five CT judges made by the previous Parliament. ${ }^{9}$ The new Parliament then appointed five new CT judges. The previous Parliament had overstepped its constitutional rights, as it only had the power to appoint three judges to the CT. ${ }^{10}$ However, the new Parliament's response was both premature and disproportionate, and amounted to blatant court 'packing'. The response was premature, as a constitutional review of the previous appointments was already underway, ${ }^{11}$ and it was disproportionate because three of the five previous appointments were fully compliant with the Constitution. ${ }^{12}$

Since December 19, 2016, three improperly appointed 'fake judges' (M. Muszyński, L. Morawski, H. Cioch) have taken part in delivering CT judgments. One (Muszyński) was even appointed as vice-president of the CT in clear violation of the Constitution. This CT handed down 88 rulings in 2017 alone, and since their appointment, the individuals in question have participated in handing down 81 rulings. This leaves the legality of most CT rulings in doubt. ${ }^{13}$

In addition, a motion filed by the MoJ in January 2017 challenging the legality of the 2010 appointment of three judges has led to their being effectively suspended by

\footnotetext{
3 Ibid., p. 65.

4 Iustitia (2018a, pp. 10-11).

5 Iustitia (2018b, pp. 92-103).

6 Iustitia (2018a, pp. 22-23).

7 Iustitia (2018b, pp. 70-89).

8 Iustitia (2018a, pp. 14-15).

9 Kustra (2016, p. 346).

10 Ibid., p. 349.

11 Helsinki Foundation for Human Rights 2016, p. 5.

12 Buras and Knaus (2018, p. 4).

13 Iustitia (2018b, pp. 96-97).
} 
the President of the $\mathrm{CT} .{ }^{14}$ Consequently, in many of the cases that have since come before the $\mathrm{CT}$, the MoJ has filed a motion for these judges to be recused. ${ }^{15}$ Given the lack of an explanation as to why the Minister's motion has still not been examined after more than three years, the situation can be interpreted as a coordinated manoeuvre by the MoJ and the CT President to unconstitutionally suspend the three judges appointed in 2010 .

As if all that were not bad enough, the decisions of the President of the CT, concerning the participation of justices in CT panels, have been arbitrary and discriminatory. Statistics show that a significant disproportion of cases are heard by judges appointed by the current Parliament, while judges appointed by the previous Parliament are clearly discriminated against. ${ }^{16}$ For instance, M. Muszyński sat on the panel for 32 cases in 2017 (J. Przyłębska was appointed CT President in December 2016). In the same period, Justice Marek Zubik, whose 2010 appointment has been challenged by the MoJ, has not sat on a single panel. Justice Zubik had sat on the panel for 342 cases (an average of 57 cases per year) prior to December 2016.

In a recently published decision of the CT, M. Muszyński admitted that the President of the Tribunal changes the judge rapporteur at will if the panel does not agree with the judge rapporteur's view of the case. ${ }^{17}$ The lack of any procedural requirement for such a change makes the practice completely opaque and wholly incompatible with the requirements of the due process of law. ${ }^{18}$

Apart from packing the CT, Parliament made six attempts to paralyze its operations by legislative enactments in $2016 .{ }^{19}$ These included:

(a) increasing the size of the majority required to revoke legislation;

(b) forcing a delay in deciding a constitutional case (by imposing a minimum of 6 months);

(c) giving the dissenting minority and the MoJ the right to impede the operation of the CT;

(d) introducing these amendments with immediate effect (i.e. without a vacatio legis).

In March 2016, the CT revoked the amendments proposed by the government. ${ }^{20}$ However, the Prime Minister claimed that the CT's decision was procedurally flawed

\footnotetext{
14 Buras and Knaus (2018, p. 6).

15 See for instance CT case Nos. Kp 4/15 and Kp 1/17 and Iustitia (2018a, p. 22).

16 Iustitia (2018a, pp. 20-21).

17 See the decision of the CT of March 22, 2018, K 9/16, in which M. Muszyński stated that the President of the CT may "change the judge rapporteur in the event that he/she does not accept the draft verdict submitted by the other members of the panel" (https://www.inpris.pl/en/whats-going-on-at-inpris/artic le/t/manipulacje-w-trybunale-konstytucyjnym/).

18 According to the law, judges are appointed to panels by the President of the CT in alphabetical order, having regard to the type, number and order in which cases are submitted to the CT. The President of the CT may derogate from these criteria and assign a judge-rapporteur when the case warrants this, especially in view of its subject-matter.

19 Radziewicz (2017, p. 24).

${ }^{20}$ CT judgment of March 9, 2016, No. K 47/15, OTK ZU No. A/2016/2.
} 
and refused to publish it, thereby rendering it inoperative. ${ }^{21}$ This was done with no regard whatsoever for the fact that $\mathrm{CT}$ rulings are final and irrevocable.

The changes at the CT have led to a loss of public confidence in the institution and consequently in the number of cases submitted to it. The significant decrease in the number of CT decisions between 2015 and 2017 is clear evidence of distrust in its impartiality and its willingness and/or ability to safeguard constitutional rights. ${ }^{22}$

\subsection{Commandeering the NCJ and the SC}

Commandeering the CT allowed the PiS government not only to remove an obstacle to promoting their unconstitutional policies, but to actively use the CT for political ends. ${ }^{23}$ An example of using the CT for political purposes - and the next step in undermining the rule of law - took place on June 20, 2017, when the Tribunal heard a case concerning the election of the NCJ. ${ }^{24}$ Prior to this decision, the NCJ had been composed in a manner intended to ensure cooperation between the legislative, executive, and judicial branches, in line with the principle of checks and balances provided for in the Constitution. ${ }^{25}$

The CT decided that certain provisions of the Act governing the NCJ were unconstitutional, ${ }^{26}$ thereby conceding to the motion of the MoJ, who had challenged those provisions while working on a putative reform of the NCJ. This decision enabled Parliament to pass a bill which gave politicians full control over the appointment and promotion of judges. ${ }^{27}$ Parliament also passed a bill amending the Courts Act to allow the MoJ to have an inordinate influence on court presidents. ${ }^{28}$

No sooner had he been given the authority to change the personnel of the NCJ, than the MoJ set out to create vacancies at the SC, so that the newly appointed NCJ could fill them with government appointees. In an unprecedented move, the Polish government promoted a bill to remove every single SC judge. ${ }^{29}$ The President of the Republic, Andrzej Duda, vetoed the bill following a public outcry. ${ }^{30}$

In September 2017, the President proposed new bills on the NCJ and the SC. ${ }^{31}$ The outcome of the presidential proposals was:

(a) the removal of $40 \%$ of the judges from the SC, including its President, thereby shortening her constitutionally enshrined term of office;

\footnotetext{
21 Iustitia (2018b, pp. 99-100).

22 Sadurski (2019b, p. 82).

23 Sadurski (2019a, p. 84).

24 Case K 5/17.

25 Iustitia (2018b, p. 85).

26 Sadurski (2019b, p.78).

27 Sadurski (2019a, p. 101).

28 Buras and Knaus (2018, p. 9).

29 Ibid., p. 6.

30 Sadurski (2018, p. 114).

31 Buras and Knaus (2018, pp. 9-10).
} 
(b) the establishment of two new SC Chambers, one of which was to be responsible for assessing the validity of elections;

(c) the appointment of a new NCJ whose judicial members were to be elected by the Sejm, which resulted in shortening the constitutionally enshrined terms of office of the NCJ's incumbent members.

As a result, Parliament elected 21 of the 25 NCJ members. Since then, the NCJ has been completely subservient to politicians, allowing them to influence the process of appointing all Polish judges, including those taking up seats in the new chambers of the SC. ${ }^{32}$

The majority of the new judicial NCJ members have close ties to the MoJ, and thus to the government. This is because most of them were chosen from among candidates who had been working at the Ministry of Justice and reporting to the MoJ, or who had been appointed court presidents or vice-presidents by him with no participation from the self-governing judicial body.

The commandeering of the CT and the NCJ is a textbook example of a technique known as "hollowing out" the institutions responsible for upholding the rule of law. ${ }^{33}$ Once the independence of those institutions is removed, they become useful props for the ruling powers to strut about the stage in a purely theatrical show of legitimacy. The attempt to bring the SC under political control was prevented by the intervention of the European Union, in particular by the interim measure issued by the Court of Justice of the European Union. ${ }^{34}$

An important element of the Polish constitutional crisis was the involvement of European institutions, including the European Commission (EC) and the Venice Commission. ${ }^{35}$ Both institutions severely criticized this assault on the institutions charged with upholding the rule of law in Poland and trenchantly laid bare the usurpatory nature of what the government had duplicitously argued was a "necessary reform of the judiciary". The Venice Commission played a crucial role in the first stage of the crisis with its opinions concerning the commandeering of the CT. It is important to stress that, unlike domestic commentators, the Venice Commission did not focus on the legalistic means used to change the rules under which the CT was to operate, but on the legal consequences of those changes. This sorely needed focus on consequences is conspicuous in the language in which its opinion was expressed. The Commission stressed that "the Parliament and Government continue to challenge the Tribunal's position as the final arbiter of constitutional issues and attribute this authority to themselves". 36 The Venice Commission was also specific about the extensiveness and pervasiveness of these consequences, arguing that "by prolonging the constitutional crisis, they [the Parliament and the Government] have

\footnotetext{
32 Ibid., p. 6.

33 Sadurski (2019a, p. 146).

34 Order of the Court in Case C-619/18 issued Dec. 17, 2018.

35 Venice Commission (formally the European Commission for Democracy through Law) is a Council of Europe independent, consultative body that advises on constitutional law issues.

36 Venice Commission (2016).
} 
obstructed the Constitutional Tribunal, which cannot play its constitutional role as the guardian of democracy, the rule of law and human rights." 37

The EC's involvement was significant during later stages of the crisis, when the ruling party attempted to take control of the NCJ and the SC. Again, the EC focused on the consequences of the government's actions, not on the formal means it deployed. The documents issued as a result of the Article 7 procedure brought against Poland on December 20, 2017, make it clear that the legislative changes introduced by the Polish government empowered the executive and legislative branches to systematically "interfere significantly with the composition, the powers, the administration and the functioning of these authorities and bodies." 38

There is no doubt that the principle-based approach of the Venice Commission and the EC exposed the government's assault on the rule of law and the separation of powers (and consequently the dismantling of checks and balances) for what it was. They might not have been completely successful, as some commentators rightly argue,${ }^{39}$ but they significantly delayed the commandeering of judicial institutions by the government, and with the assistance of the European Court of Justice, prevented the most detrimental changes, e.g. the removal of SC judges.

\section{The Nature of the Political Attack on the Rule of Law in Poland}

For those who have been following the Polish constitutional crisis from abroad, all this may seem to be a routine spat between the judiciary and the other branches. Analyzed in Schmittian terms, ${ }^{40}$ law, as a system of rules, is an obstacle to the realization of the current political will, and must therefore yield to politics. When they clash, politics represents a set of values external to law; law, in turn, represents its own values, mostly formal, which cannot be reconciled with the external values of politics. Analyzed in Radbruchian terms, ${ }^{41}$ law secures legal safety, politics promotes effectiveness. When they clash, politics trumps law to change society in accordance with the political will, even if this involves breaking the law.

From this perspective, the nature of the political attacks on the rule of law in Poland may seem familiar from history: these are attacks through which political values prevail over legal values, and procedural justice yields to the promotion of material justice defined by those in power. One can call those attacks "old school", as they recall the actions against the formal values of law undertaken by the authoritarian regimes of the twentieth century. A typical attack of this kind can be found in Lenin's 1917 attacks against "formality":

\footnotetext{
37 Ibid.

38 Reasoned Proposal in Accordance with Article 7(1) of the Treaty on European Union regarding the Rule of Law in Poland, paragraph 173. See Kelemen and Pech (2019).

39 See Pech and Scheppele (2017), who present an excellent overview of the European Commission's actions against Poland in 2016 and 2017.

40 Schmitt (2008).

41 Radbruch et al. (2006).
} 
"We'll tell the people that its interests are higher than the interests of democratic institutions. There's no need to go back to the old prejudices, which subordinated the interests of the people to formal democratism". ${ }^{42}$

Lenin's intentions are explained as follows by a contemporary commentator: "Thus, in a critical choice between the electoral voice of the people and the prerogatives of state power, 'formality' became a stick with which to beat 'democracy", ${ }^{43}$

Shocking as it is, similar statements have been made almost a hundred years later in the centre of Europe, specifically Poland, a country deeply affected by the trauma of totalitarianism. Kornel Morawiecki MP, during the debate on nullifying the appointment of five CT judges on November 26, 2015, said:

"Law is something important but it is not sacred. (...) Above law stands the good of the Nation. If law interferes with this good, we shall not treat law as something inviolable or unchangeable. What I say is this: law shall serve us! Law that does not serve the nation is lawlessness!"

The above quotations may suggest that the attacks on the rule of law in Poland resemble the old-school authoritarian attacks, which were intended to establish a clear hierarchy in which law was subservient to politics. However, the kinds of attacks on the rule of law currently encountered in Central and Eastern Europe are different. Politicians might declare that politics should prevail over law, in unguarded moments, but they at least pay lip service to the law when they execute their policies. They have to convince the general public that they are acting in accordance with the law. Thus, they employ ostensibly legal tools to achieve illegal, unconstitutional goals.

K. L. Scheppele refers to this phenomenon as "autocratic legalism". ${ }^{44}$ As she convincingly argues, contemporary autocrats are well aware that a frontal assault on the rule of law would be met with fierce resistance in any contemporary society, where it would immediately be perceived as a prelude to totalitarianism. ${ }^{45}$ Therefore, the new-school attacks on the rule of law and checks and balances are disguised as perfectly legal actions on the part of democratically-elected political parties, and are most often presented to the public as "reforms" aimed at improving the operations of the institutions that they are actually demolishing. As Scheppele stresses, the defining characteristic of autocratic legalism is that the autocrat ceremoniously observes the letter of the law or rather, certain legal provisions and only in the narrowest sense, as a way of consolidating political power. ${ }^{46} \mathrm{~A}$ similar strategy, deployed outside Central Eastern Europe as well, has been described by A. Puddington, who righly claims that:

\footnotetext{
42 Lenin's speech from 1 December 1917 (quoted by Burbank 1995, p. 38)

43 Ibid.

44 Scheppele (2018, p. 548).

45 Ibid., pp. 571-572.

46 Ibid., p. 548.
} 
"The leaders of today's authoritarian systems devote full- time attention to the challenge of crippling the opposition without annihilating it, and flouting the rule of law while maintaining a plausible veneer of order, legitimacy, and prosperity." 47

The difference between the old-school and new-school attacks on the rule of law lies in the would-be autocrat's perception of constitutionalism. Whereas twentieth century dictators saw it as the main obstacle to acquiring unlimited power and attacked it head-on, ${ }^{48}$ their twenty-first century counterparts see it as a means to an end, to hollow out constitutional institutions and to pervert and misuse constitutional tools for their own purposes. ${ }^{49}$ As Scheppele argues, this disguised attack on the rule of law is most frequently executed by enacting a new constitution that lacks genuine liberal values (as in Hungary), or by enacting legislation that effectively removes constitutional checks and balances (as in Poland). ${ }^{50}$ In every case, "the autocratic legalists often make a giant public show of being governed by and governing within the law" ${ }^{51}$ In one sense, this article is a response to K. L. Scheppele's call to those working in the field of constitutional law to track the way the new autocracy works in detail and to better document troubled cases so as to be able to learn from them. ${ }^{52}$ The cases analyzed below are examples of the variety of autocratic legalism that belongs to the realm of legal interpretation rather than legislation. In this, it resembles the model of autocratic legalism proposed by J. Corrales. ${ }^{53}$ This "interpretive" autocratic legalism can be perceived as a supplement to K. L. Scheppele's seminal analyses, which focus on dismantling the rule of law by creating new laws rather than reinterpreting existing ones.

As paying lip service to the rule of law is being used as a smokescreen for attacking the independence of the judiciary, it is crucial that this strategy be exposed for what it is - and for two reasons. First, the covert nature of the new-school attack makes it difficult for the public to realize that an attack is actually being waged. As a consequence, it sees no necessity to defend the judiciary, and in the absence of public pressure, politicians can feel unconstrained in their actions. Second, attacking judicial independence in a manner that gives the appearance of complying with the letter of the law makes it difficult for the judiciary to strip away the veneer of legitimacy of these attacks and to show the public what is really happening. Again, as Scheppele argues, "because the legalistic autocrats deploy the rhetoric of democracy and the methods of the law, observers find it hard to see the danger until it is too late." 54

\footnotetext{
47 Puddington (2017, p. 1).

48 See Scheppele, pp. 560-561.

49 Kelemen and Pech (2018).

50 Scheppele, pp. 573-574.

51 Ibid., p. 569.

52 Ibid, p. 583.

53 See Corrales (2015) and K.L. Scheppele's discussion of the differences between Professor Corrales' and her own versions of "autocratic legalism". Scheppele, p. 548.

54 Scheppele, p. 571.
} 
Neither the legalistic smokescreen erected by the PiS nor my discussions of the legal intricacies of the constitutional interpretation proposed by the government should mislead the reader into thinking that the dismantling of the rule of law in Poland is in any sense legally justified. On the contrary, as W. Sadurski puts it, the PiS has pulled off nothing short of a coup d'état, ${ }^{55}$ as their violations of the rule of law are not mere oversights or misinterpretations but a deliberate, systematic and sustained repudiation of domestic and supranational standards. ${ }^{56}$ People as well as institutions have been brutally attacked behind this legalistic smokescreen. A series of disciplinary procedures have been launched against prominent judges and lawyers, and there have been several examples of harassment. ${ }^{57}$

When analyzing the Polish case, it is important not to conflate the two general perspectives of the legalistic smokescreen produced by the new villains of the twenty-first century (Scheppele's term). First, there is the perspective of the professional lawyer. From this perspective, none of the argumentation adduced by the PiS has any legal validity whatsoever and it was completely predictable that the Polish government would lose every single infringement action brought by the EC. ${ }^{58}$ The other perspective is that of the layperson or the non-specialist press. From this perspective, pseudo-constitutional arguments based on the narrowest "letter of the law" interpretation (i.e. a facile interpretation of selective provisions presented in isolation and out of context, with no regard to constitutional principles) have sufficed to create a legalistic smokescreen. Moreover, this distorted and misleading constitutional interpretation has even convinced some professional lawyers that the government's actions are legally justified. ${ }^{59}$

That the Polish government's legal argumentation was bogus for the majority of professionals in no way detracts from the main thesis of this article, viz. that the legalistic smokescreen put up by the government during the Polish constitutional crisis was instrumental in dismantling the rule of law, and - more importantly - that mature, principle-based legal reasoning would have blown away this legalistic

\footnotetext{
55 See 'What is going on in Poland is an attack against Democracy', Interview with Verfassungblog, July 15, 2016: https://www.verfassungsblog.de/what-is-going-on-in-poland-is-an-attack-against-democracy/.

56 Pech and Kochenov (2019).

57 A particularly shocking example of undue pressure being exerted on persons holding judicial office is the case of Judge Waldemar Żurek, NCJ spokesman and a former court press officer of the Kraków Regional Court. Judge Żurek has been one of the most vocal critics of the government's takeover of the judiciary, and he used to appear in the media quite frequently. A description of the actions taken against this judge is set out in a resolution adopted by the Meeting of Representatives of the Kraków District Judges (2018). Judge Żurek was interrogated five times by the public prosecutor's office and the Central Anti-Corruption Bureau during the course of groundless proceedings that dragged on for almost eighteen months. The pretext was an inspection of a declaration of financial interests. Contrary to the law, these proceedings had been conducted for six months without being formally opened. Measures were taken to harass and interrogate Judge Żurek's parents, who were both over seventy years old at the time, and unjustified checks were carried out on the financial standing of Judge Żurek's wife (who was six months pregnant at the time). In addition, the media ran a smear campaign against Judge Żurek. This brought on a wave of threats and hate speech in the form of numerous telephone calls and text messages.

58 I am grateful to an anonymous reviewer for pointing out this issue.

59 See the SC decision concerning the CT's authority to suspend the proceedings before the SC, discussed on pp. 33-35).
} 
smokescreen and more vigorously and effectively defended the country's constitutional and legal institutions. This argument would apply a fortiori if Poland's legal culture were not so non-formalistic.

My claim is that the effectiveness of the attacks on the rule of law has at least partly depended on having them disguised as completely legal actions. The smokescreen of legality deployed by the PiS has made it difficult for the layperson to see the sheer illegality of the government's actions. The resulting false sense of legal propriety has left the public disinclined to consider the brutality of these attacks or their consequences. This smokescreen would be far less effective if Polish legal culture were less formalistic, i.e. if constitutional principles were generally recognized as a fully legitimized element of the legal order. The attackers would then have to resort to more direct tools. According to Scheppele's model of autocratic legalism, these would be less effective because they could not be presented to the public as legalistic. In other words, the ruling party would not be able to conceal the brutal illegality of their depredations, and so the social pushback would be much stronger.

Traditionally, however, judges in Central and Eastern Europe have been trained in the spirit of judicial formalism, according to which the formal compliance of one's actions with the letter of the law is a sufficient basis for their legality. ${ }^{60}$ The illegality of the new-school attacks on the independence of the judiciary can be revealed only by showing that they infringe constitutional principles, even if they comply with isolated, bright-line rules. Revealing this illegality involves the application of a nonformalistic strategy of judicial reasoning - a strategy which does not come naturally to Central and Eastern European judges for reasons of historical legacy.

The non-formalistic strategy of judicial reasoning is principle-based. It holds that the law not only consists of rules, but also more general standards, such as the principles of constitutional and international law. In contrast to the traditional, continental model of adjudication, in which judges are seen as mouthpieces of the law, the non-formalistic model of judicial reasoning recognizes the crucial role of constitutions and supranational law in domestic adjudication. The principles derived from these sources, particularly from EU treaties, the European Court of Justice case law, and the European Convention on Human Rights, should not only be recognized and applied by constitutional courts, like the CT in Poland, but also by regular courts, which should be guided by them when interpreting domestic laws. ${ }^{61}$

As shown further in the article, the non-formalistic strategy helps to ensure the realization of constitutional goals and to forestall any attempt to misuse the Constitution for illegitimate purposes. In the Polish case, the main problem with finding new ways of interpreting old laws is that this interpretation neglects the principles of constitutional and international law and it also completely ignores established precedents. In doing so, it fails to achieve the objectives for which these principles were designed.

\footnotetext{
${ }^{60}$ Matczak et al. (2010, p. 82).

${ }^{61}$ On the differences between a formalistic and non-formalistic model of adjudication see Galligan and Matczak (2007).
} 
The commentators have pointed out that the new autocrats in Central Eastern Europe

tend to conveniently forget is that while Article 4 TEU does impose on the EU an obligation to respect its Member States' national identities, it certainly does not give a blank cheque to national authorities to adopt 'reforms' designed to violate fundamental EU principles such as the rule of law and judicial independence, and to unilaterally decide on their compatibility with the national constitution and EU law. ${ }^{62}$

Such a distorted, formalistic interpretation is only possible in a formalistic legal culture, i.e. one that only accepts rule-based legal reasoning, and which does not perceive constitutional principles as law proper but as non-binding desiderata. Legal reasoning that contemptuously disregards constitutional principles leads to constitutionalism being undermined by formalistic legality. ${ }^{63}$ The reason for this, as Scheppele argues, is that the values of constitutionalism are superseded by the formal values of the law. This is inevitable when literal compliance with a particular, technical constitutional regulation is sufficient to justify an autocrat's action, even if that action flies in the face of the substantive principles enshrined in the Constitution and supranational law. ${ }^{64}$

Unfortunately, one of the most enduring legacies of the Communist era is the judicial reluctance to apply general principles to specific cases. Consequently, judges in the post-Communist countries of Europe are often helpless when the revelation of the illegality of an action hinges on proving that it infringes general principles despite being superficially compliant with the letter of the law.

In the next sections of this article, I present examples of the new-school attacks on the rule of law, and then explain how the educational legacies of the Communist era make it so difficult for the judiciary to defend itself against them.

\footnotetext{
62 Kelemen, Pech, p. 73.

63 Scheppele, p. 563 ("When legality undermines constitutionalism, it is because the values of the new laws have superseded the values of constitutionalism rather than the other way around, as constitutionalism itself requires.”).

64 Scheppele enumerates those principles that characterize constitutionalism as a normative political theory (the protection of rights, the ability to check power, the rule of law, toleration, pluralism, and equality), and juxtaposes these values, as expressed in constitutional principles, with the formal requirements of legalism. (Scheppele, p. 562). One difference between Scheppele's approach and my own is that she understands legalism as tantamount to positivist standards for enacting statutes, whereas I focus on interpretative rather than legislative standards. Another is that Scheppele stresses the significance of liberalism, understood as a moral position, whereas I am more interested in liberal values as expressed in positivistic legal acts (e.g. constitutions, EU law, and international conventions). This second difference is conspicuous in Scheppele's short discussion of the Hart-Fuller debate (Scheppele p. 562-563). She sees autocratic legalism in the light of a law-morality relationship, whereas I see it in the light of a ruleprinciple relationship, i.e. an intralegal relationship.
} 


\section{Examples of a New-School Attack}

\subsection{Example 1: CT}

As we have seen, the first stage of the rule-of-law crisis in Poland started when the newly elected PiS-majority Parliament attempted to paralyze the CT by imposing new statutory organizational and procedural rules. In doing so, the governing majority drew on Art. 197 of the Constitution, which reads: "The organization of the Constitutional Tribunal, as well as the mode of proceedings before it, shall be specified by statute".

This was presented as the sole basis for Parliament's right to regulate the operations of the CT as it deems fit. No reference was made to constitutional principles stipulating the functions of the constitutional review performed by the $\mathrm{CT}$, and no reference was made to the principle of the independence of the judiciary, or the separation of powers.

\subsection{Example 2: NCJ}

In order to take control of the NCJ, the PiS once more deployed a legalistic smokescreen. Their new NCJ law was justified by a formalistic constitutional interpretation of Art. 187 Section 1 of the Polish Constitution:

"1. The National Council of the Judiciary shall be composed as follows:

1) the First President of the Supreme Court, the Minister of Justice, the President of the Supreme Administrative Court and an individual appointed by the President of the Republic;

2) 15 judges chosen from amongst the judges of the Supreme Court, common courts, administrative courts and military courts;

3) 4 members chosen by the Sejm from amongst its Deputies and 2 members chosen by the Senate from amongst its Senators."

Point 2) of this regulation had been consistently understood as giving the judges the right to appoint the judicial members of the NCJ ever since the Constitution came into effect in 1997. The PiS decided, however, that while the judicial members had to be chosen from amongst the judges, they were not going to be chosen by the judges. In 2017, they introduced a bill which provided that the judicial members of the NCJ were to be appointed by the Sejm. ${ }^{65}$

${ }^{65}$ Filipek (2018). 


\subsection{Example 3: SC}

As we have seen, the first proposed bill provided for the instant removal of all incumbent SC judges. The constitutional justification for such a brazen move was derived from Article 180 of the Polish Constitution, which reads:

"1. Judges shall not be removable.

(...)

5. Where there has been a reorganization of the court system or changes to the boundaries of court districts, a judge may be allocated to another court or retired with maintenance of his full remuneration."

Art. 180 Section 5 was presented as an isolated basis for the removal of judges, with no reference to other constitutional regulations, e.g. Art. 31 Section 3, which expresses the proportionality principle and requires that any limitations of rights be proportionate to the goal of the limitation. In particular, how the very limited reorganization of the SC could justify the removal of all judges was never explained.

\section{The Tool of Deception: A Specious Constitutional Interpretation}

The foregoing examples show that the perpetrators of the new-school attack on the rule of law deploy a specific type of legal argumentation: one that I will call a "specious constitutional interpretation". This involves selectively choosing a particular constitutional provision and interpreting it in isolation from other provisions, the Constitution as a whole, black-letter constitutional principles, and established case law. The defining feature of this type of interpretation is its much-vaunted compliance with individual bright-line rules of the Constitution, even if the consequences of the actions based on those rules infringe general constitutional principles, in particular the independence of the judiciary and the separation of powers.

Returning to the interpretation of Art. 197, which gives Parliament the right to regulate proceedings before the $\mathrm{CT}$, there was no reference to any of the other constitutional provisions that regulate the relationship between the legislature, the executive, and the judiciary; in particular, the Article was interpreted without any reference to Art. 10, which mandates the separation and balance of powers. The fact that a regulation imposed on the CT by Parliament complies with Art. 197 is not sufficient to make it compliant with the Constitution, especially if it hinders the CT from performing its constitutional duties.

The interpretative approach shown in the example of the NCJ follows a similar pattern. The rationale for amending the way the judicial members of the NCJ are appointed was based on an assumption that there is a lacuna in Art. 187 Section 1 Point 2 of the Constitution, i.e. that the Constitution does not stipulate who is to appoint the judicial members of the NCJ, but only from amongst whom they should be appointed. According to the interpretation championed by the government, that lacuna can be legitimately filled by depriving the judiciary of the right to appoint their own representatives in the NCJ and instead to grant it to the legislative branch. 
Again, the provision concerning the appointment of the judicial members of the NCJ was read in complete isolation from the other provisions of the Constitution. In particular, no systematic interpretation was applied, i.e. if both the legislative and the executive branches have their representatives in the NCJ and have the right to appoint them themselves, then consistency demands that the judicial branch be accorded the same right (Art. 187 Section 1 Points 1 and 3). Bearing in mind that the NCJ is charged with "safeguarding the independence of courts and judges" (Art. 186 Section 1), and that "the system of government of the Republic of Poland shall be based on the separation of powers and balance between the legislative, executive and judicial powers" (Art. 10), this interpretation clearly contradicts the axiology of the Constitution.

Following that pattern of interpretation, the following thought experiment illustrates why having the legislative branch elect the representatives of the judicial branch cannot be reconciled with the values of the Polish Constitution, in particular the separation and balance of powers. Imagine that the Polish Constitution established a body to safeguard the equality of the sexes (let us call this imaginary body the "National Council of Equality"). If Poland had such a constitutional Council, and it comprised $50 \%$ percent men and $50 \%$ women, the interpretation proposed by the PiS with regard to the NCJ would allow its women members to be appointed by the men. As this thought experiment shows, a balance between two or more parties with competing interests cannot be achieved by privileging one of them with the right to elect the representatives of the others. The "representatives" of the other parties are not representatives in any meaningful sense of the word and the "safeguard" of equality is not a safeguard in any meaningful sense of the word.

Similarly, an acontextual interpretation of Article 180, which gives Parliament the right to remove judges in exceptional cases connected to the reorganization of courts, does not hold up to legal scrutiny. This Article cannot be correctly interpreted without reference to Article 31 Point 3, which expresses the principle of proportionality. The reason why Article 31 Point 3 is relevant is that the removal of a judge is an exceptional act, and should therefore only be undertaken as a last resort. A superficial reorganization of the $\mathrm{SC}$, which does not render the judges redundant, is an insufficient justification to remove them from their posts.

The implicit nature of these attacks on the mechanism of the rule of law could only have been thwarted by a sophisticated defence; one that relied on a holistic interpretation of the Constitution and a departure from the familiar formalistic interpretative strategy. As we will see, this sort of strategy was only adopted in one of the three cases just cited. Even in that case, however, it encountered public criticism, which demonstrates that a non-formalistic approach to deciding constitutional cases does not come naturally to lawyers educated in a formalistic legal culture. Before we can see why the defence was not sufficient, we need to analyze whether the judiciary can defend itself from the depredations of the legislative and executive branches, and if so, how. Its right to self-defence and the theoretical framework for conceptualizing it are by no means uncontroversial. 


\section{The Nature of the Defence (or Self-Defence) Against the Attacks on the Rule of Law}

All three branches of the Polish government have claimed that their rights have been endangered or that they have been attacked by the others. The legislative branch was the first to make such a claim: in November 2015, Stanisław Piotrowicz MP, now a CT justice, claimed that the main reason behind the first amendment to the statute regulating the operations of the $\mathrm{CT}$ was the conviction that the $\mathrm{CT}$ would block the necessary reforms the new government planned to carry out. ${ }^{66}$ The same reason was given for introducing the new CT statute, enacted in December 2015. During a hearing before the CT justifying the changes to the statute, Marek Ast MP stated that it had been introduced because of a "state of necessity". Thus, the new regulations concerning the CT were perceived by the legislature as "pre-emptive" self-defence. $^{67}$

Another example was the statement, dated March 23, 2016, by the Speaker of the lower chamber of the Polish Parliament, Marek Kuchciński, who said that he had to protect the rights of Parliament against the CT and its usurpations of power. ${ }^{6}$ One of the alleged usurpations was the judgment dated March 9, 2016, in which the CT revoked the new statute on the organization of the $\mathrm{CT}$ and the proceedings before it, without using the same act as the basis for its decision. A further alleged usurpation was the earlier decision of Andrzej Rzepliński, the President of the CT, not to allow three persons appointed to already occupied positions of CT judges to fulfil the related functions. ${ }^{69}$

Necessity was also evoked by Justice Rzepliński to justify the actions of the CT during the crisis. He did so in November 2016, when explaining why the CT panel deciding on the constitutionality of the regulations for electing a new CT President included five judges instead of a full panel. ${ }^{70}$ His stated reason was the impossibility of forming a full panel, due to the decision of the President not to accept the appointment of the judges elected by the previous Parliament.

The statements quoted above show that the parties to the Polish constitutional crisis have perceived it as a clash between the branches of government, and justify their actions as self-defence. What is the nature of this self-defence?

Nicholas Barber's paper "Self-Defence for Institutions" provides a useful tool for analyzing the complex relationship between the branches of government. In order to identify the nature of the defence against the attacks on the rule of law in Poland, I propose to expand on the theoretical tool proposed by Barber and to show that the elaborated tool has more explanatory value than the original one.

\footnotetext{
${ }^{66}$ See https://www.radiomaryja.pl/informacje/s-piotrowicz-alarmuje-tk-stanie-sie-sedzia-we-wlasnejsprawie/.

67 Gill (2006).

68 "The rights of Parliament have been infringed".

69 Kustra (2016, p. 354).

70 See https://www.tvn24.pl/polska/prezes-tk-wyjasnia-swa-decyzje-vis-maior-ra689968.
} 
The main assumption behind Barber's theoretical construction of institutional self-defence is that every branch of government has at its disposal several institutional tools that can be used to limit the powers of another branch. Those tools can be active in nature ("swords" in Barber's terminology) or passive ("shields"). ${ }^{71}$ As far as the relationship between legislatures and judiciaries are concerned, an example of a legislative sword is the judiciary's "power to strike down executive or legislative actions that interfere with access to the courts", ${ }^{72}$ an example of a judicial shield is that "decisions of the courts are protected from the scrutiny of the Legislature". 73

Barber's paper is illuminating and his application of the concept of "self-defence" to the context of the separation of powers merits discussion. In his approach, the tools of self-defence include two types of institutional instruments: regular and extraordinary. The former includes virtually all the legal powers at the disposal of a branch of government, their common feature being that their use is lawful. The latter, by contrast, are ad hoc tools which can be instances of misuse or even unlawful use. ${ }^{74}$ Hence, in the case of constitutional courts, tools of self-defence include both a constitutional review performed by a court that has been constitutionally empowered to perform such a review, and an ultra vires attribution of a previously non-existing power to the same court by its judges.

An all-compassing concept of self-defence would in such a case conflate two completely different groups of actions. How, then, can this conflation be removed and Barber's idea improved? My proposal is to look at the self-defence of institutions from the theoretical perspective of criminal law, in particular, the criminal law theory of self-defence. I am aware that Barber devised his theory for the needs of constitutional law, and applied it to constitutional theory. ${ }^{75}$ Nevertheless, I believe that examining the concept of self-defence through the lens of another legal discipline, and one which has devoted much more time and effort to developing the theory of self-defence than constitutional theorists, can be illuminating, in particular, by revealing the variety of measures that can be taken in self-defence.

The criminal law concept of self-defence is used in the context of an extraordinary and prima facie unlawful action that is post factum justified as exceptionally admissible by law. Self-defence is a legal justification for the use of force that absolves the accused from criminal liability for harm inflicted on the life, health or property of another on the ground that such action was necessary to prevent harm to his/her own life, health or property. As such, in criminal law, actions performed in self-defence are extraordinary and prima facie illegal. Thus, one can kill a person in self-defence, but one cannot press criminal charges in self-defence, as this is a completely legal action, and, as such, does not require any post factum justification.

\footnotetext{
71 Barber (2013, p. 558).

72 Ibid., 562.

73 Ibid., 561.

74 Ibid., 562.

75 Barber refers to A. Hamilton's works and his term "mutual defence", when he presents the origin of his theory (see Barber p. 558). I am grateful to an anonymous reviewer for bringing this issue to my attention.
} 
Self-defence in criminal law involves an ad hoc balancing of competing values. Killing in self-defence is still killing, and criminal liability can only be avoided by proving that it was justified under the circumstances, i.e. that the competing values (in this example, the life of the aggressor versus that of the defender) are at least equally balanced. Regular actions openly admissible by law do not involve any ad hoc balancing - they are completely legal because the lawmaker did the balancing during their enactment and reached a positive result. A case in point is legally admissible abortion when the mother's health is endangered. The lawmaker balanced the value of the mother's health and the value of the unborn child's life and decided to give priority to the former.

In his conceptualization of self-defence for the needs of constitutional law theory, Barber includes both explicitly legal instruments, and legally debatable emergency measures. From the perspective of the criminal law concept of self-defence, this conceptualization is over-inclusive. Such a conceptualization does not allow for a distinction between those actions for which a branch of government may be held legally liable and those for which it cannot. In the same way that an individual cannot be held legally liable for pressing criminal charges, a constitutional court cannot be held liable for deciding a constitutional case. However, just as an individual can be held liable for exceeding the limits of self-defence, an official can be held liable for the misuse of power.

To avoid conflation of the legally valid and the legally doubtful, my proposal is to enhance Barber's concept of institutional self-defence, originally tailored for constitutional law, with the theoretical elements of self-defence in criminal law. This would result in treating the explicitly legal means that a branch of government has at its disposal not as tools of self-defence, but (for want of a better term) as tools of self-assertion (of a branch's function). The group of sensu stricto tools of selfdefence would then be limited to the actions that have no clear basis in law or which are even illegal. Those tools are traditionally called praeter legem (beyond the law) or contra legem (against the law) actions, and are contrasted with completely lawful actions (secundum legem).

Two benefits derive from this step. First, it allows for qualifying the actions undertaken by a particular branch of government as the choice of the lesser evil, and this choice constitutes the core of the balancing of interests in the criminal concept of self-defence. The praeter legem and even the contra legem actions of a constitutional court can be justified if it can be shown that they sacrificed a less valuable legal good (e.g. deference to a constitutional habit) to promote a more valuable one (e.g. the protection of citizens against retroactive laws). Thus, mirroring the elements of the criminal law concept of self-defence in its institutional counterpart enables a more rigorous evaluation of the actions of the various branches of government, and provides more certain grounds for their eventual justification.

Second, it allows assessment criteria that have a longstanding tradition in criminal law to be applied to institutional self-defence, i.e. within the realm of constitutional law. These criteria include necessity, proportionality, retreat and immediacy. ${ }^{76}$

76 Sangero (2006). 
All of them are readily applicable to prima facie unlawful institutional actions, but completely inapplicable to the explicitly legal tools of institutional self-promotion. There is little sense in debating whether a constitutional court fulfilled the criterion of immediacy in its regular actions of assessing the constitutionality of a statutory act. Nor is there much sense in examining whether the legislature can be held liable for not retreating in Barber's example of dissolving the legislature and calling fresh elections. Obviously, these actions can be assessed in terms of political expediency, but not their legality, which is indisputable.

The optimal way of showing why one conceptualization of self-defence has a better explanatory value than another is to put them into practice and apply both to a real-life event. The first stage of the Polish constitutional crisis, which centred on controlling the CT, is a case in point. Let us see how the concept of institutional self-defence, enhanced and supplemented with the theoretical elements borrowed from its criminal law counterpart, can explain what happened in Poland and how culpability can be allocated between the parties involved.

In the first few months of the crisis, Parliament undertook a wide variety of actions. First, it appointed two judges (lawful actions, secundum legem), amended the statute regulating the organization of the CT without a vacatio legis period, and nullified the previous Parliament's appointment of three judges (actions contra or praeter legem). According to the concept of self-defence based on the criminal law tradition, only those actions that are legally doubtful justify such a defence: selfdefence cannot be pleaded as a justification for assaulting a police officer attempting to search one's home pursuant to a search warrant (secundum legem). This issue is extremely important in assessing the actions of the parties in the Polish crisis.

The actions undertaken by the CT in its judgment dated March 9, 2016 were expressis verbis based on the Polish Constitution. The decision not to base the proceedings on the statute at issue, i.e. whose compliance with the Constitution was being decided by the $\mathrm{CT}$, was made in meticulous observance of the Constitution (Art. 195 and Art 8 Section 2). The former states that the judges of the CT are subject only to the Constitution while performing their official duties (and not to regular statutes); the latter allows the judges to apply the Constitution directly to the case at hand. As a consequence, the question that arises is whether the legislative branch was entitled to defend itself against a legal action by the CT. According to Barber's original model of self-defence, the answer is most likely in the affirmative. Yet, according to the criminal law model, the legislature is no more entitled to self-defence in this case than is a home owner when a legal search warrant is being executed.

The value of the enhanced concept of institutional self-defence can be seen when one assesses the actions of the participants of the Polish constitutional crisis on the basis of whether they satisfy the criteria of necessity, proportionality, immediacy and retreat. Again, it is difficult to find any justification for the actions of the legislative branch on any of these counts. As it turned out, the unconstitutional changes introduced in 2015 to the regulations concerning the CT had already been planned 
by the previous PiS government in $2007 .{ }^{77}$ As such, they cannot be justified in terms of self-defence, as they do not fulfil the criteria of necessity or immediacy. It is clear that a state of necessity cannot last for nine years, and an action planned nine years earlier is hardly an immediate response to an attack.

Nor did the legislature's actions meet the criteria of proportionality or retreat. Changes to the regulations concerning the CT were proposed by the legislature six times between December 2015 and November 2016. Despite the CT's judgment that the legislature was entitled to appoint only two judges in December 2015, Parliament appointed five. The failure of such actions to fulfil the relevant criteria make them ineligible for consideration as parliamentary self-defence.

Applying the same more exacting criteria to the judicial branch presents a very different outcome. First, the judicial branch did not initiate the crisis. As we have seen, the legislative branch fired the opening salvos by amending the statute on the CT and appointing five CT judges in December 2015. These actions threatened the independence of the CT. Second, the actions by the CT were proportional and restrained. One example is the decision of March 9, 2016. Both in the oral and written reasons for the decision, Justice Biernat went to great pains to explain that the CT did not apply the statute under assessment to the procedure of its own assessment in order to avoid a catch-22 situation (the circularity of assessing the constitutionality of a regulation on the basis of that regulation), and to avoid the risk of undermining the legality of the CT's own decision in case the regulation is found unconstitutional (a decision issued on an unconstitutional basis is flawed). ${ }^{78}$

All the above examples show that if anyone is entitled to evoke the self-defence argument, it is the judiciary, not the legislature. The record shows that Parliament was the aggressor. Subsequent claims that Parliament's rights had to be protected were a politically expedient smokescreen designed to mislead the public. Even those actions presented as self-defence against the judiciary's assaults on the rights of the legislature appear pre-meditated, gratuitous and disproportionate. Even if those actions had been taken in self-defence, they would have been excessive and ultimately indefensible.

Under the circumstances, the Polish CT and its judges, as targets of the attack, had the right to defend themselves. ${ }^{79}$ The instruments used by the CT were either completely legal or were justified actions praeter legem. In the case of completely legal actions, no resort to the concept of self-defence is required. The admissibility of the praeter legem actions resulted from the context in which they were undertaken. As proportionate and immediate reactions to the risk of losing its independence, the CT's actions were paragons of self-defence. ${ }^{80}$

Having applied an improved concept of institutional self-defence at the general level of the relationship between Parliament and the CT, let us examine the specifics

\footnotetext{
77 See the article in Newsweek Polska, dated May 10, 2016.

78 Radziewicz (2017, p. 26).

79 Kustra (2016, p. 365).

80 Radziewicz (2017, p. 29): “The Tribunal chose a moderate, individual variant, neutral as regards the tenor of the regulation and legalistic".
} 
of the judicial defence against the attacks of the legislative and executive branches in the three previously discussed cases. Were the attacks irresistible or was the defence badly prepared to fight back?

\section{Strength of the Attack or the Weakness of the Defence?}

My main thesis in this article is that the rule-of-law crisis in Poland has not been caused so much by the strength of the political attack but by the weakness of the defence mechanisms that should have been triggered once the rule of law was attacked. Amongst those mechanisms one is of utmost importance - the maturity of legal culture, a key feature of which is the ability to carry out complex legal reasoning when interpreting legal text.

Before discussing that, however, I would like to pose the crucial theoretical question of whether the choice of interpretative methodology (e.g. between a formalistic and non-formalistic interpretative strategy) is a tool of self-defence or a tool of selfassertion for judicial institutions. The answer to this question depends on whether choosing an interpretative methodology is a completely legal action that can be undertaken by the court, or whether it is a praeter or contra legem action.

My position is that if the chosen interpretive methodology induces the application of well-entrenched interpretative arguments, it cannot be treated as praeter or contra legem. As shown below, there is nothing in the least extraordinary about the non-formalistic legal reasoning that could have defended the judiciary against the new-school attacks. Indeed, the application of constitutional principles along with bright-line rules is far from unprecedented. I therefore contend that, even when the expanded concept of the self-defence of institutions, expounded above, is applied to Polish judicial institutions, a non-formalistic interpretation strategy can only be a tool of self-assertion.

Yet, even if the interpretative methodology chosen by the courts is a tool of selfassertion, and as such a secundum legem action, adopting an anti-formalistic interpretation has been perceived within Polish legal culture as praeter or even contra legem. At the same time, the acontextual legal interpretation of the Constitution, championed by the legislative and executive branches of government, has not been perceived as praeter or contra legem. That sort of flawed constitutional interpretation can only be effectively refuted by judicial reasoning if the reasoning is sufficiently complex. But if a judicial culture's preferred form of reasoning is formalistic argumentation, such a refutation is difficult, if not impossible. Studies analyzing the strategies of judiciaries in Central Eastern Europe show that the legal culture in this region is formalistic ${ }^{81}$ and that this is one of the legacies of Communism. As a consequence, the legal culture has not developed adequate tools to defend itself against the recent attacks on the rule of law. Understanding the nature of judicial formalism reveals why this form of legal reasoning is an inadequate defence against the newschool attack on judicial independence.

81 Matczak et al. (2010). 
According to Frederick Schauer, the crucial feature of judicial formalism is the reductionism of interpretive premises. ${ }^{82}$ This reductionism assumes that out of many available interpretative premises judges may choose only a small number, usually associated with the plain meaning of the text or the original intention of the lawmaker. As a consequence, judicial formalism has a strong preference for bright-line, mostly locally applicable rules over general principles, the latter being perceived as too vague to guide judicial actions.

As such, judicial formalism is especially poorly suited to revealing the real nature of the attacks on the rule of law which are based on specious, acontextual legal interpretation. The main reason is that the formalistic judicial mindset cannot not see beyond what is ostensibly legal. In particular, formalistic assessment sanctions acontextual interpretation by a reluctance to apply constitutional principles along with the rules.

Alternative, non-formalistic judicial strategies which would reveal the deception behind the new-school attack on the rule of law are available. An alternative to the acontextual constitutional interpretation can be found in a systemic (holistic) interpretation of the Constitution, according to which bright-line constitutional rules would be interpreted in the light of the principles derived from the Constitution, EU law, including the jurisprudence of the European Court of Justice, and international law, in particular, the European Convention on Human Rights. This holistic interpretation should also be functional and purposive, i.e. it should safeguard constitutional values and ensure the realization of constitutional objectives, thereby pre-empting the misapplication of narrowly and acontextually construed constitutional rules on the part of the new autocrats. ${ }^{83}$

Unfortunately, a holistic, non-formalistic argumentative strategy has been deployed in only one of the three cases discussed above. The CT was able to defend itself against the specious interpretation of Article 197 of the Constitution by refusing to base the constitutional review of the new law concerning the CT's operation on that very same law, even though it had been enacted with immediate effect and - from a formal point of view - should have governed proceedings before the CT. The CT's legal argumentation against carrying out proceedings on the basis of the new law was based directly on constitutional principles, including the independence of judges and their right and responsibility to apply the Constitution directly to the case at hand. Unfortunately, the CT's readiness to deploy principle-based argumentation to protect the independence of the judiciary is an exception rather than a rule. As a constitutional court whose source text is principle-based, the CT has a particular inclination to use principle-based reasoning, but this inclination is not an entrenched element of the Polish legal culture as a whole.

In other cases, going beyond the letter of the law, into the realm of real-life consequences, is an effort than no formalistic lawyer could make. When applied in constitutional interpretation, formalistic legal reasoning leads to a primitive formalistic constitutionalism. In Poland's case, an especially astonishing version of this kind of

\footnotetext{
82 Schauer (1988) and Matczak (2018)

${ }^{83}$ Barak (2005, p. 88).
} 
constitutional interpretation has been presented in one of the presidential draft bills concerning the NCJ and the SC. The effect of the new law on the NCJ is to be that the terms of office of the current members is to expire before the constitutionallyestablished time. The substantiation to the draft law claimed, however, that the new law is constitutional because "The 4-year term of office established in the Constitution would only be infringed if a 3-year term of office were imposed in the statute" ${ }^{84}$ One can clearly see that unconstitutionality is perceived here as a semantic contradiction between the sentences of the Constitution and of statutory law, and not the irreconcilability of their real-life effects. The very fact that such an absurd formalistic argumentation was provided by the drafters implies that the legal culture is indeed underdeveloped.

Also, the interpretation relied upon to substantiate the change in appointing the judicial members of the NCJ has been accepted by many. The formalistic argument that, as the Constitution has nothing to say about who is to appoint the judicial members of the NCJ, this shortcoming can be rectified by having this function arbitrarily assigned to a person or entity of Parliament's choosing, has been considered perfectly valid. This is a prime example of where an anti-formalistic interpretative strategy should be deployed: one based on a holistic approach to the values on which the Constitution is predicated. Any lacunae within the constitutional text should be filled in the manner that best reflects the underlying axiology of the Constitution, i.e. upholding the balance of powers (as per Art. 10 Section 1), not by granting one dominion over the others.

The formalistic interpretation favoured by the government was likewise widely accepted in the SC example. Instead of a holistic reading of the Constitution, which would have construed Parliament's right to remove judges in the case of a court reorganization as an exceptional tool that should be used sparingly and proportionally, a formalistic reading was considered legitimate. As a result, what was meant as an exception became the rule, and a reorganizational change that did not affect the work of the majority of SC judges (viz. establishing two new SC chambers) was used as a pretext for removing all SC judges from their posts. Similarly, when the President of the Republic later came up with an alternative proposal (lowering the judicial retirement age and applying it to the incumbent judges), a formalistic line of argument prevailed. The right to set the retirement age for judges cannot reasonably be formalistically interpreted in isolation from other constitutional principles, such as the independence of the judiciary. Nevertheless, it was.

As mentioned above, the legalistic argumentation provided by the Polish government successfully concealed their authoritarian intentions from the public. More worrying, however, is that some judges were misled as well. The only plausible explanation for this is that their formalistic approach to legal reasoning blinded them to the government's misuse of the law. This is conspicuous in yet another political incursion into the judicature.

\footnotetext{
84 https://www.prezydent.pl/download/gfx/prezydent/pl/defaultaktualnosci/5425/18/1/uzasadnienieglosowanieimienne-jednolity-wersjaostateczna.pdf, p. 9.
} 
Just after his being sworn in as the President of the Republic, Andrzej Duda, supported by the PiS party, pardoned Mariusz Kamiński, who had served as the head of the secret service during the first Law and Justice government (2005-2007), and who has since become the minister with responsibility for the secret services (2016 to date).

According to the Polish Constitution, the President may exercise the right of pardon at will, yet in this particular case he did so before a judgement had been issued by the criminal court of last instance, which was still deliberating the case against Kamiński. Given the "innocent until proven guilty" rule, this resulted in the unusual circumstance of a President of Poland effectively pardoning an innocent person. The motive behind that extraordinary move, which took place in anticipation of a general election, was all too clear: once convicted, Kamiński would be ineligible for public posts, which could prevent him from taking office. President Duda claimed that he had merely "helped out" the court, "freeing" it from a cumbersome case.

The court of appeal, before which Kamiński's case was heard, terminated the case after the President's pardon. However, the injured party appealed and the case went to the SC, which was to decide on the scope of the President's right to pardon. The SC's proceedings were eventually blocked by a motion filed by the Speaker of the lower chamber of the Polish Parliament to the CT, which was at that time already fully controlled by the PiS. The Speaker based his motion on Article 189 of the Polish Constitution, which reads "The Constitutional Tribunal shall settle disputes over authority arising between central constitutional organs of the State."

The Speaker's motion to the CT ostensibly sought to resolve an alleged dispute over authority between the SC and the President, even if no such dispute had arisen: the SC never wanted to exercise the President's right to pardon - rather, it wanted to assess the impact of the premature pardon on the pending court case. Given the lack of a dispute, the real motive behind the Speaker's motion was to achieve the compulsory, formal effect of such a motion: the suspension of the SC's proceedings in which the President's power of pardon was being assessed. Unfortunately, the SC, although not yet commandeered by the PiS, was unable to come up with a non-formalistic line of argument, i.e. one that would have included an examination of the Speaker's motives and the consequences for the separation of powers (the Speaker's motion was an attempt to have the legislature prevent the judiciary from assessing the actions of the executive). Instead, the SC accepted the formal effect of the motion and suspended its proceedings. As a consequence, Kamiński has been able to continue performing his duties as a minister. Since the suspension, the CT has taken no steps to resolve the alleged dispute between the President and the SC. This was another example of how "the new autocrats come to power not with bullets but with laws". 85

The above-described case is an example of misusing a formal right (the Speaker's right to file a motion to the $\mathrm{CT}$ ) to achieve an unconstitutional effect (to hinder the court from deciding a case). What it has in common with the previously discussed cases is that to resolve them properly, general principles must be applied. In the

${ }^{85}$ Scheppele, p. 582. 
previous cases, one has to apply the constitutional principle of judicial independence to refute the politically-motivated interpretation of the Constitution. In this case, one has to take into consideration the motives of the formally legal actions to infringe the independence of the judiciary (which is constitutionally protected) and their consequences for that independence.

Again, the reluctance to apply general principles to the case at hand is a typical feature of a formalistic judicial approach. This feature has facilitated the government's limitation of the independence of the judiciary, as the judiciary has proven unwilling and/or unable to expose and rebuff the deliberate misuse of the law. This can be defined as using lawful means to achieve unlawful ends. As in the cases discussed above, the Speaker acted in consistency with formal legal rules, here the rule that empowered him to file a motion to the CT. However, he did so with the illicit motive of preventing the SC from hearing the Kamiński case. Neither the SC nor the public could discern any illegality in the Speaker's manoeuvre, as they did not consider general principles (the separation of powers, his motives or the consequences of what he had done). This is all too typical of formalistic, post-communist legal culture.

In the previous section, I have tried to elucidate the concept of institutional selfdefence with the assistance of criminal law theory. Following this interdisciplinary approach, I now contend that the anti-formalistic strategy in defending the independence of the courts is best elucidated with recourse to competition law theory. Competition, like judicial independence, is protected by law, and constitutional law can learn a great deal from competition law as to how this protection should work. The guiding principle of competition law and policy is substance over form, i.e. the formal means used by the actors are deemed illegal if they have the effect of restricting competition. ${ }^{86}$ The formal legality of the means (e.g. exercising the right to set a price) is vitiated if it restricts competition, which can happen if e.g. the price is temporarily set below cost to drive out competitors. A similar principle should be observed in constitutional law, i.e. the formal legality of the means used by the legislature (e.g. using its right to reorganize the court or to set the retirement age for judges) cannot be permitted to serve as a pretext for trammeling judicial independence. The anti-formalistic strategy in legal reasoning protects the ends, not the means.

\section{The Paradox of Judicial Formalism in Central Eastern Europe}

The prevalence of formalistic argument in the Polish legal culture indicates a degree of underdevelopment insofar as the ability to perform complex judicial reasoning is concerned. It is paradoxical that judicial formalism used to be deployed by the

\footnotetext{
${ }^{86}$ See Art. 101 of the Treaty on the Functioning of the European Union, which prohibits "all agreements between undertakings (...) which have as their object or effect the prevention, restriction or distortion of competition within the internal market" (emphasis added).
} 
judiciary to defend the autonomy of the law under Communism. ${ }^{87}$ At that time, the autonomy of the law had to be protected from principles that were irreconcilable with the rule of law (e.g. the socialist concept of justice, in particular its relation to freedom). ${ }^{88}$ This formalistic approach, based as it was solely on the text of statutes and with no reference to those alien principles, ensured that they had no impact on the application of the law.

Nowadays, when formalism is deployed by politicians to infringe the autonomy of the judiciary, the reluctance to apply principles is detrimental. Since the fall of Communism, legitimate principles constitutive to the rule of law have been introduced into the legal system to increase its resilience to such attacks, the independence of the judiciary being a case in point. The judiciary's historical aversion to deploying principles in judicial reasoning precludes their use of principles in its defence, notwithstanding that these principles are neither alien to the legal system nor detrimental to the rule of law.

This can be better understood once it is accepted that the law can enter into three different relations with values. Some values are internal formal values of law, similar to those identified by Fuller in his concept of the internal morality of law. ${ }^{89}$ They include the requirement to enact legal rules that are abstract and general, the ban on retroactive laws, the requirement to publish laws, etc. Those internal values are formal as they set requirements as to the form of the legal rules and do not predefine their content.

Another set of values with which law may enter into a relation are internal nonformal values, a case in point being the principle of judicial independence. Those values have been introduced into the law by the decision of the lawmaker. As an element of law, such values are not perceived as elements of morality, which is external to law. As a consequence, they are not separated from law (like the requirements of external morality are) and may indeed have a validating effect on other rules. In this, they are unlike external requirements, which, according to the separation thesis expressed by legal positivists, ${ }^{90}$ cannot render laws invalid. To give an example, if a statutory rule does not meet the requirements set by the constitutional principle of the independence of judiciary, that statutory rule will be found null and void in the process of constitutional review. Further, those internal values are non-formal as they predefine the content of other legal rules, in contradistinction to the previously discussed internal formal values, which do not do so. For example, the independence of the judiciary sets specific requirements as to the content of statutory rules concerning the operations of the CT and the legal status of judges.

Finally, there are also external non-formal values - values which can be pursued by a particular political power, yet are not introduced into the law (thus external). An example of such a value can be "the good of the nation" invoked by Kornel Morawiecki and quoted at the beginning of this paper. The "good of the nation" is

87 Pałecki (2004, p. 18).

88 Simpson (1976).

89 Fuller (1964).

90 Hart (1958). 
a value external to law as it had not been enacted as a part of the law by the lawmaker, and apparently cannot be achieved by actions that are compliant with that law. Therefore, Morawiecki claimed that the good of the nation is more important than the law, which must yield to it. This type of value is of a non-formal nature as it attempts to influence the content of the legal rules or the way the legal rules are applied. That influence is, however, questioned by legal positivists in their separation thesis. As a consequence, the external non-formal values remain outside the legal system, as they cannot be reconciled with either internal formal or internal non-formal values.

Under Communism, we witnessed a clash between the internal-formal legal values and the external, non-formal legal values: the former were used to defend the law's autonomy against the latter. The 1952 Polish Constitution did not recognize the separation of powers. That value was therefore perceived as an external, non-formal value - a political one. In fact, its status was an element of political negotiations during the transition from the communist regime to the democratic one. The situation changed with the collapse of Communism, when formerly external values were internalized and enshrined in successive constitutions. As internal constitutional values, they are available to judges as arguments in judicial reasoning, but studies show that judges have not always acknowledged the change in the status of those values. ${ }^{91}$ As a consequence, those values are still being treated as political rather than legal.

If the attacks of contemporary politicians were similar to historical ones, i.e. based on the promotion of external values (the good of the nation) over internal ones, judges could use their old strategy of calling on internal formal values. However, politicians do not take this old-school track. Rather, they misuse the law by manipulating internal formal values to achieve their goals. The old strategy of defence is powerless against this new strategy of attack. What would work is a strategy which uses internal, non-formal values (e.g. separation of powers) against abuses of power intended to subvert the law.

\section{Conclusion}

The purpose of this article is to argue that the reasons for the Polish constitutional crisis are more complex than is usually assumed. The crisis was caused by a political attack on the rule of law, and what has made this attack so successful is the inability of the post-communist legal culture to defend itself. The attack itself was of a new kind - it deployed formalistic legal reasoning to justify the legal changes concerning the independence of the judiciary, despite the fact that those changes were obviously designed to infringe the constitutional principles protecting that independence.

As I have tried to show, the judiciary has a right to defend itself from these sorts of attacks. The defence, however, has to be based on comprehensive, sophisticated and non-formalistic argumentation that involves principle-based, systematic and teleological legal interpretation. Unfortunately, this task has so far proved beyond the

91 Matczak et al. (2010). 
capabilities of Polish legal culture - principally because of a reluctance to counter argumentation based on the bright-line rules with argumentation based on constitutional principles. This reluctance derives from an entrenched conviction that nonformal values, even if enshrined in the Constitution, are not law proper.

The Polish experience may serve as a lesson for those who value the rule of law and struggle to enforce it. If the formalistic approach to the application of laws, with its reluctance to apply constitutional principles, remains the archetype of judicial ethos, the enemies of the rule of law will prevail. Yet, changing this approach is not an easy task. It is going to require profound changes in legal education, and if it is to have any chance of success, it will additionally have to involve a reappraisal of the criteria used by appeals courts to assess the judgements of those of lower instance. As long as formal compliance is the only criterion for such an assessment, with any attempt to apply principles not only unwelcome but actively discouraged, ${ }^{92}$ the legal culture in Central Eastern Europe will remain all but defenceless against the new kind of attack on its main tenet.

\section{Funding None.}

\section{Compliance with Ethical Standards}

Conflict of interest The author(s) declare that they have no competing interests.

\section{Availability of data and material N/A.}

Code availability N/A.

Open Access This article is licensed under a Creative Commons Attribution 4.0 International License, which permits use, sharing, adaptation, distribution and reproduction in any medium or format, as long as you give appropriate credit to the original author(s) and the source, provide a link to the Creative Commons licence, and indicate if changes were made. The images or other third party material in this article are included in the article's Creative Commons licence, unless indicated otherwise in a credit line to the material. If material is not included in the article's Creative Commons licence and your intended use is not permitted by statutory regulation or exceeds the permitted use, you will need to obtain permission directly from the copyright holder. To view a copy of this licence, visit http://creativecommons.org/licen ses/by/4.0/.

\section{References}

Barak A (2005) Purposive interpretation in law. Princeton University Press, Oxford Barber NW (2013) Self-defence for institutions. Camb Law J 72(3):558-577

Buras P Knaus G (2018) Where the law ends. The collapse of the rule of law in Poland-and what to do.

Batory Foundation, May 29, 2018, 4 https://www.batory.org.pl/upload/files/Programy\%2520operac yjne/Forum $\% 2520$ Idei/ESI-ideaForum_Batory\%2520-\%2520Poland $\% 2520$ and $\% 2520$ the $\% 2520 \mathrm{e}$ nd\%2520of\%2520the\%2520Rule\%2520of\%2520Law.pdf. Accessed 15 May 2020

Burbank J (1995) Lenin and the law in revolutionary Russia. Slavic Rev 54(1):23-44

92 See https://www.icj.org/poland-end-unjustified-disciplinary-proceedings-against-judges/. 
Corrales J (2015) Autocratic legalism in Venezuela. 26 J Democr 37:38-45

Filipek P (2018) The New National Council of the judiciary and its impact on the supreme court in the light of the principle of judicial independence. Problemy Współczesnego Prawa Międzynarodowego Europejskiego I Porównawczego XVI:177-196

Fuller LL (1964) The morality of law. Yale University Press, New Haven

Galligan D, Matczak M (2007) Formalism in Post-Communist Courts. Empirical study on judicial discretion in Polish administrative courts deciding business cases, [w:] Judicial Reforms in Central and Eastern European Countries, ed. Ramona Coman and Jean-Michel De Waele, Vanden Broele, 2007, pp 227-252

Gill TD (2006) The temporal dimension of self-defence: anticipation, pre-emption, prevention and immediacy. J Confl Secur Law 11(3):361-369

Glasius L (2018) What authoritarianism is ... and is not: a practice perspective. Int Aff 94(3):515-533

Hart HLA (1958) Positivism and the separation of law and morals. Harv Law Rev 71(4):593-629

Helsinki Foundation for Human Rights (2016) The constitutional crisis in Poland 2015-2016. Report https://www.hfhr.pl/wp-content/uploads/2016/09/HFHR_The-constitutional-crisis-in-Poland-20152016.pdf. Accessed 15 May 2020

Iustitia Polish Judges Association (2018a) Response to the white paper compendium on the reforms of the Polish justice system. Presented by the Government of the Republic of Poland to the European Commission. https://www.iustitia.pl/images/pliki/response_to_the_white_paper.pdf. Accessed 15 May 2020

Iustitia Polish Judges Association (2018b) The response of the Polish Judges Association "Iustitia" to the White Paper on the Reform of the Polish Judiciary Presented to The European Commission by The Government of The Republic of Poland. https://www.iustitia.pl/images/pliki/response_to_the_white _paper_full.pdf. Accessed 15 May 2020

Kelemen RD, Pech L (2019) The uses and abuses of constitutional pluralism: undermining the rule of law in the name of constitutional identity in Hungary and Poland. Camb Yearb Eur Legal Stud 21:59-74

Kelemen RD, Pech L (2018) Why autocrats love constitutional identity and constitutional pluralism: lessons from Hungary and Poland, Working Paper no. 2-September 2018, Reconnect; https://www. reconnect-europe.eu/wp-content/uploads/2018/10/RECONNECT-WorkingPaper2-Kelemen-PechLP-KO.pdf. Accessed 10 Aug 2020

Kustra A (2016) Poland's constitutional crisis. From court-packing agenda to denial of constitutional court's judgments, Toruńskie Studia Polsko-Włoskie XII, Toruń, pp 343-366

Matczak et al (2010) Constitutions, EU law and judicial strategies in the Czech Republic, Hungary and Poland. J Public Policy 30(1):81-99

Matczak M (2018) Why judicial formalism is incompatible with the rule of law. Can J Law Jurisprud 31(1):61-85

Meeting of Representatives of the Kraków District Judges (2018) Resolution. https://www.konstytucyjny. $\mathrm{pl} /$ resolution-of-the-assembly-of-representatives-of-judges-of-the-regional-court-in-krakow-of-26february-2018/. Accessed 10 Aug 2020

Pałecki K (2004) Stressing legal decisions. Basic assumptions. In Biernat T et al (eds) IVR 21st World congress, Lund, Sweden, August 12-18, 2003, Law and politics; in search of balance. Polpress, Cracow

Pech L, Scheppele KL (2017) Illiberalism within: rule of law backsliding in the EU. Camb Yearb Eur Legal Stud 19:3-47

Pech L, Kochenov D (2019) Strengthening the rule of law within the European Union. Diagnoses, recommendations, and what to avoid, policy brief, 2019, Reconnect. https://www.reconnect-europe.eu/ wp-content/uploads/2019/07/RECONNECT-policy-brief-Pech-Kochenov-2019June-publish.pdf. Accessed 10 Aug 2020

Puddington A, (2017) Breaking down democracy: goals, strategies, and methods of modern authoritarians. https://www.freedomhouse.org/sites/default/files/June2017_FH_Report_Breaking_Down_ Democracy.pdf

Radbruch G, Litschewski Paulson B, Paulson SL (2006) Statutory lawlessness and supra-statutory law. Oxf J Legal Stud 26(1):1-11

Radziewicz P (2017) Refusal of the Polish constitutional tribunal to apply the act stipulating the constitutional review procedure. Rev Comp Law XXVIII:24-40

Reasoned Proposal in Accordance with Article 7(1) of the Treaty on European Union regarding the Rule of Law in Poland. https://eur-lex.europa.eu/legal-content/EN/TXT/?uri=CELEX\%3A52017PC0835 
Sadurski W (2018) How democracy dies (in Poland): a case study of anti-constitutional populist backsliding. Revista Forumul Judecãtorilor Nr 1(2018):104-178

Sadurski W (2019a) Poland's constitutional breakdown. OUP, Oxford

Sadurski W (2019b) Polish constitutional tribunal under PiS: from an activist court, to a paralysed tribunal, to a governmental enabler. Hague J Rule Law 11:63-84

Sangero B (2006) Self-defence in criminal law. Hart Publishing, Oxford

Schauer F (1988) Formalism. Yale Law J 97(4):509-548

Scheppele KL (2018) Autocratic legalism. Univ Chicago Law Rev 85:545-583

Schmitt C (2008) Constitutional theory, transl. J. Seitzer. Duke University Press, Durham

Simpson E (1976) Socialist justice. Ethics 87(1):1-17

Venice Commission (2016) Poland-opinion on the act on the constitutional tribunal, 108th plenary session, CDL-AD (2016)026-e, Venice, 14-15 Oct 2016

Verfassungsblog (2016) What is going on in Poland is an attack against democracy', W. Sadurski's Interview with Verfassungblog, 15 July 2016. https://www.verfassungsblog.de/what-is-going-on-inpoland-is-an-attack-against-democracy/. Accessed 10 Aug 2020

Publisher's Note Springer Nature remains neutral with regard to jurisdictional claims in published maps and institutional affiliations. 